\title{
Learning From The History Of Tangerang In The Colonial Period For The Better Future Of Indonesia
}

\author{
Lilie Suratminto \\ \{lilie.suratminto@budhidharma.ac.id\} \\ Buddhi Dharma University
}

\begin{abstract}
We find the name Tamgaram, from the book Suma Oriental written by Tomé Pires (1513) [1] a Portuguese adventurer who joined the Portuguese armada in their search for spices in the archipelago. Regarding Tangerang, during the period of the Company or VOC (Vereenigde Oost Indische Compagnie) sugar production which provided enormous profits for the Company. The increase in Javanese and Sundanese population was caused by the defeat of Sultan Agung against Batavia 1627-1629. After the Chinese massacre in Batavia 1740, there were many exodus Chinese to the Tangerang's area. With a qualitative method through the deconstruction approach, a picture of the failure of the Dutch East Indies Government policy will be obtained in eliminating anti-Chinese sentiments that each time cause upheavels that are very detrimental to the government at that time. The Dutch East Indies government in its policy has divided the society into three groups namely Europeaan, Vreemde Oosterlingen and Inlander. The Chinese belongs to the second group and privates land concessions who make them landowners and they can act arbitrarily like 'a king' against their land tenants. Anti-Chinese sentiments incite hatred of the Chinese that provokes resistance. This could have been prevented if the Colonial Government had changed its policy regarding social stratification and approaches to the native population of Tangerang. In the conclusion of this research, the Government of Indonesia in making policies should reflect from the socio-cultural history of Tangerang to avoid from the repeated story, for the better future.
\end{abstract}

Keywords: Tangerang, ommelanden, anti-Chinese sentiment, invited colonialism

\section{Introduction}

What we call Tangerang today according to history during the pre-colonial period is the west and east of the Cisadane River. Actually in Tangerang there are two rivers namely the Cidurian River and the Cisadane River, but in the manuscript sources, the Cisadane river is more commonly referred to by the Dutch as Untung Jawa river. If we look at the current Cisadane river is very wide and deep, we certainly suspect that a long time ago a lot of ships that were passing by carrying merchandise to be brought to the port at the mouth of this river. Tomé Pires a Portuguese sailor in his adventure following the Portuguese fleet (2013) written 
in his book Suma Oriental mentions Tangerang by the name Tamgaram as depicted on their map [1][2].

The location of Tangerang is geographically located between two centers of power namely Jayakarta and Bantam. During the heyday of the Bantam Sultanate, Jayakarta was a vassal of the Sultanate of Bantam because Fatahillah as the ruler of Jayakarta was called by his fatherin-law to replace him in the Sultanate of Cheribon. So that the Prince of Jayakarta could concentrate more on the government of the sultanate of Cheribon, Jayakarta was handed over to the first Sultan of Bantam, Sultan Maulana Hasanuddin who was the son-in-law of Sultan Trenggono from Demak. Since then Bantam has become the largest maritime kingdom in Southeast Asia.

With the arrival of the Portuguese into the Archipelago the kingdom of Demak tried to stem Java from the influence of the Portuguese who spread Christianity. Indeed the main mission of the Portuguese besides trading was three G namely: Glory, Gold and Gospel.[3] Therefore the Sultan of Demak sent Maulana Hasanuddin to defend Bantam and the Sultan of Cheribon sent Fatahillah his son-in-law to prevent Portuguese relations with King Surawisesa from Pakuan. Between the Bantam and Jayakarta regions, the border is marked, the Cicadane river. With the agreement that the area west of the river includes the Bantam region, while the one to the east of the Cisadane river is the Jayakarta region. The sign in the Bantams-Javanese language is called tenger [e pepet or schwa], and the designation is tengeran.

Later, when the Makassar Fortress (Benteng Makassar) in Tangerang was established and the guards who were the Bugis Makassar people, who in their language did not recognize vocal e pepet and the final consonant $[n]$ or $[\mathrm{m}]$ is pronounce as diftong [ng]. Therefore, they pronounce tengeran become tangarang, Over the course of time their speech changes to [tangerang].

In the VOC agreement with the son of Sultan Ageng Tirtayasa (1682) was also marked by the placement of a monument as a sign of the boundaries of the Company and Bantam in Grendeng (west side of the Cisadane river in Karawaci area). This monument in Javanese language is "tenger" [4].

The tengeran In the form of a monument has an inscription as follows:

Bismillah peget Ingkang Gusti

Diningsun juputparenah kala Sabtu

Ping Gasal Sapar Tahun Wau

Rengsena Perang nelek Nangeran

Bungas wetan Cipamugas kilen Cidurian

Sakabeh Angraksa Sitingsun Parahyang-Titi.

Translated in the Bahasa Indonesia:

In the name of Allah Almighty

We took the opportunity on Saturday

The fifth of Sapar Tahun Wau

After the war we planted a monument

To maintain the eastern boundary of Cipamugas

And the west is Cidurian

All of them guarded the land of Parahiyang-Titi.

On June 27, 1596 the Compagnie van Verre fleet under Cornelis de Houtman and Gerrit van Beuningen consisting of three ships traders namely Hollandia, Amsterdam, Mauritius and 
a Duyfken hunter ship, for the first time in the port of Karangantu Bantam[5]. At that time in the sultanate of Bantam was still mourning because the Sultan of Bantam died in Palembang while fighting there and his son as heir to the kingdom was still a child. In the sultanate of Bantam there were many conflicts of interest resulting in the empire becoming increasingly weak. Wijayakrama of Jayakarta saw that Bantam was getting weaker and he tried to attract foreign traders to stop at Sunda Kelapa Harbor [6]. At that time in the sultanate of Bantam was still mourning because the Sultan of Bantam died in Palembang while fighting there and his son as heir to the kingdom was still a child. In the sultanate of Bantam there were many conflicts of interest resulting in the empire becoming increasingly weak. Wijayakrama of Jayakarta saw that Bantam was getting weaker and he tried to attract foreign traders to stop at Sunda Kelapa Harbor. He rented places in the mouth of the Ciliwung river to the British and the Dutch. Ranamanggala considered that Wijayakrama had violated Bantam's authority. Wijayakrama was then captured and exiled and at the same time Ranamanggala and his troops from Bantam and Jayakarta faced the VOC troops under J.P. Coen In this war the Bantam troops can be driven out and in the same place J.P. Coen founded the city of Batavia (1619). Batavia, was become the headquarters of the Company's trade in Asia and South Africa. To build the empty city of Batavia the Company brought Chinese people from Bantam to build the city under the leadership of a Chinese captain named Souw Beng Kong (1619) whose tombs can still be seen today on Jalan Pangeran Jayakarta Jakarta [7] [4], [8].

\section{Research Method}

With qualitative research methodology and the theory of deconstructivism in history we can see the problem becoming more objective, namely by an inventory of data and then we turn our mindsets, we ask when, why and how a historical event can occur in reverse. In other words, we return collective memories that have become connotative or mythological and even ideological by dissecting them in reverse [9]. Derrida, the originator of the deconstructivism theory states that all events, history, buildings, words, sentences are something that is constructed by humans. Therefore, if we want to know the actual situation we need to dismantle or deconstruct again.

So far we have always blamed the Company as the culprit who with the politics of devide et impera divided our nation [10]. With the deconstruction method we then list questions whether the mistake was actually on our side. We ask why history is written that and why? Behind an event there must be certain purposes from the chronicler. The people are only seen as objects by the authorities. We have never been invited to think about why these regions are arbitrarily divided among them without looking at the interests of the inhabitants of that region. We take the example of the London Tractat in 1824 where the British and Dutch arbitrarily divided the colony into their own. Johor and Singapore were exchanged for Bengkulen [11]. Ethnic Malays, both on the Malacca Peninsula and on the archipelago separated by the colonial authorities. If we read history there are many examples of the arbitrariness of both colonial and indigenous rulers. This is really a devide et impera conspiracy to divide the Malays.

So far, history has always revolved around events involving important people from the authorities. We are just small people as their objects. We have never been involved in deconstructing it. If we look at various internal conflicts in a kingdom or sultanate in the archipelago, it must always begin with an internal conflict over the struggle for influence and 
power. Then the pattern is the same, one party seeks outside help. The outsider here is the VOC, a trading company that always counts on the multiplied profits. Now we see the problem objectively, who is guilty, who invited and who was invited? Have we ever thought objectively, why did the conflict occur? The king has too many wives and children? Can the king or sultan be fair to all his children or wives? It can be concluded that the Company as a trading company was actually invited by one of the parties. VOC has been invited. The Company must be happy and if necessary, there are many divisions in this country so that the Company can obtain many benefits [12], [13]. If we go through the VOC paleographic manuscripts, there are a lot of manuscripts containing contents of agreements and debt bills because the Company has helped them in solving problems.

There are several examples of conflicts which brought the Company's advantage in relation to Bantam.

First, the conflict between Sultan Haji and his father Sultan Ageng Tirtayasa from the sultanate of Bantam. Sultan Haji asked for help from the Company. The conflict ended with the victory of Sultan Haji. The Company was allowed to build the Speelwijk Fortress and establish its power in Bantam (1682) [14]. Second, the succession conflict by Ratu Syarifah, who considered "her husband crazy" because of Ratu Syarifah's ambition to raise her son from her previous husband to become the Sultan of Bantam. It also involved the Company which ultimately made Bantam's strategic areas fall into the Company's hands. In return the Company was able to expand the Tagerang region on the west bank of the Cisadane river, which at the time Tangerang had only covered the eastern and a small part of the western area of the Cisadane river [5]. Third is the event of the destruction of the Surosowan Palace at the beginning of the rule of the Bataaf Republic under Governor General Herman Willem Daendels in which the sultanate of Bantam was abolished forever and replaced with a new government system.

From the study through the deconstructivism approach it was proven that VOC was actually the invited colonialism in the Archipelago.

\section{Results And Discussion}

At the beginning of the city of Batavia (1619) the city was very quiet. All the indigenous population moved out of their cities to settle in other areas of Bantam, therefore the ommelanden area was also quiet. Many plantations were abandoned by their owners. They moved away from Batavia. If they stayed there they were accused of defending the Company by the Bantam authorities, To fill the vacancy of the city of Batavia the Company brought Chinese people from Bantam and other regions to build the city of Batavia. Agricultural and plantation lands around Batavia by the Company can be taken and owned by anyone, as long as they are able to cultivate the land and part of the proceeds are handed over to the Company in exchange for land rent [15]. The first goal was for the rescued population to fill the city of Batavia again. Their energy is needed. Second, for security. If there are enemies from the outside they will come first with the residents who also protect their property [10]. Third, for cash income of the Company from land leases. According to Company regulations there are two types of land ownership, namely erfpacht land, land leased for business and state land or landsdomein. Mauk District and Tangerang District are included in the erfpacht land category.

Based on Resolutie van het Casteel Batavia dated. March 3, 1809 administratively Tangerang including Batavia en Ommelanden was directly handled by the Company's 
authorities. The land of Tangerang is divided into several parcels which are then sold to Europeans and Chinese who later become private landowners. This private land increasingly developed during the Dutch East Indies colonial government [12], [15]. After there was a peace agreement between the Company and the Sultanate of Bantam the Tangerang or Ommelanden region was called the West Kwartier area with the capital of the Afdeling in Tangerang. Both the land on the west bank and the east bank along the Cisadane River were used as the Company's business area. Because after the war with Bantam many vacant lands were abandoned by their owners because they fled to other areas in the Bantam region, so the land was distributed and its status became a land of particulates. In Babakan, for example, a sugar factory was established. Finally, a lot of land is cultivated by Chinese landlords because basically the Chinese are businessmen who have traditionally been used to trade everywhere, while the indigenous population is more like a farmer, fisherman and home industry for example making a typical Tangerang hat which is very famous. The Chinese in Tangerang are also known as boat makers.

The aim of the Company to make the ommelanden region into private land was first to obtain large profits from sugar and coffee plantations and rice for the logistical supply of the inhabitants of Batavia. Secondly, for the stronghold against Bantam's attack because the Company did not yet one hundred percent believe about the realization of the agreements agreed between the sultanates of Bantam and the VOC. This was because the Bantam sultan often delayed the payment of costs incurred by the VOC in helping to solve the problems. At the time of the riots of the Chinese Ethnic Massacre in Batavia on 9 October 1740 in the area of Tangerang there were 131 sugar factories [8]. Most of the owners are Chinese. At that time the export of sugar became excellent. It absorbs a lot of human resources from sugar cane planting to grinding, packing and exporting. After the price of sugar in the world market fell, a crisis occurred especially in the area of sugar plantations in Tangerang.

In 1680 the Sultan of Bantam, Sultan Sumedang and the Sultan of Cheribon held a meeting in Pasanggrahan in the area south of Tigaraksa, the first city of Tangerang. Pasanggrahan as the capital of the kamaulanan area covers the areas of Tangerang, Jasinga and Lebak. These three regions are each governed by three tumenggungs.

Tumenggung from Sumedang, namely Tumenggung Aria Yudanegara, Jasinga area by Tumenggung Aria Wangsakara and Lebak area by Tumenggung Aria Santika. This triad is called Tigaraksa (three leaders).

The Company ordered the three tumenggungs to build a fortress. Aria Yudanegara was assigned to build a stronghold on the north bank of the Cisadane River between Cikokol and West Kedaung. Furthermore, this fort is known by the name of Makassar Fortress because the guardians are Makassar Bugis who were brought in from Makassar after the peace agreement with Sultan Hasanuddin of Makassar in the Bungaya Agreement th. 1666. At that time the Company was led by General Speelman. Tumenggung Aria Wangsakara built a fort at Lengkong (now called Benteng Lengkong Sumedang).

Although there was a peace agreement between the Company and Sultan Haji on April 17, 1684, the three Tumenggung tried to fight the Company because they were not satisfied with the Company's treatment which they said was unfair because the Company was very protective of the landlords (Chinese) and ignored indigenous interests. But all three were unable to get rid of the Company. In a battle Aria Santika died in a battle at Kebon Besar. He was buried in Kramat Asem Batu Ceper (1717).

Tumenggung Aria Yudanegara died in Cikokol (1718) in order to invade Jatinegara. He was later buried in the Sangiang area. Tumenggung Aria Wangsakara died in Ciledug (1720). He was buried in Lengkong Kulon (Lengkong Sumedang) in the Legok area. With the death 
of the three Tumenggungs, then in 1720 the end of Tangerang sovereignty was considered. Lengkong Sumedang is called a Babakan area or a new place with a very Sundanese nuance, both in clothes, building style and language.

The Chinese in Tangerang work in agriculture, trade and the handicraft industry. Indigenous farmers and also people working on land owned by Chinese landlords. They have to pay one fifth of cuké from the harvest. In addition they have to pay rent for land used for houses, yards and fields [10]. They have to carry out a kind of heren dienst art, which is community service, for example, maintaining bridges making and tidying public roads. If they do not carry out the comments they can be convicted. A farmer who is obedient to fulfill his obligations he can work on his land for generations.

The Chinese who are the owners of land are hereditary called téko land which is called téko land. In the 19th century, the Tangerang Chinese under their livelihoods were farmers, pig farmers, boat repairers. Some indigenous people work in the home industry of making bamboo hats or pandanus hats. Tangerang hat is famous to foreign countries. Has been exhibited at international exhibitions in Paris.

On Friday 23 May 1923 there was a fight between a number of residents of Kampung Tegalkunir and the Kebonbaru. The problem of trivial misunderstanding but because of exhaled ethnic problems becomes out of control. The reason is only trivial that Gudel, the son of a farmer is suspected of not paying when buying sticky rice at the son of Lim Oetan who owns a rice field in Kebonbaru. The misunderstanding resulted in Lim's child being taken to the hospital and Gudel being killed by the Chinese. This incident caused a displeasure and anti-starch of the indigenous population to the Chinese.

The rebellion was carried out on February 10, 1924. The uprising was led by Kaiin. In the circumcision event of Kaiin's stepchildren he announced that he would become a "king" in the land of Pangkalan and Kampung Melayu. The Chinese will be expelled. Cuké and the arts will be abolished. The rebels were divided into five groups and moved towards Pangkalan and Kampung Melayu. They ransacked the office and all the art letters were torn apart. In short because they lost personnel and their weapons, Kaiin could be captured in Tanah Tinggi. Although his efforts to drive out the Chinese were unsuccessful, he was considered as a hero because he had defended the peasants and Kaiin as the main characters.

From the description of the process of formation of private land in Tangerang which results in the existence of a gap between the indigenous population and the landlords. This negatively impacted relations between Chinese and natives all the time. Whenever there is an economic problem the Chinese are almost always a scapegoat. Chinese are always being targeted. Remember the events of the slaughter of ethnic Chinese in Batavia, the Chinese War in Java. During the Republic of Indonesia's independence there were also events that were based on ethnic Chinese hatred such as two historic events which were the G.30 S riots in September 1965, and the May 1998 riots. Events with a background of sentiment towards ethnic Chinese should have been prevented through Government policy [16].

During the reign of H.W. Daendels Dutch East Indies Java is divided into three regions namely:

1. De Stad Batavia, de Ommelanden en Jacatrasche Preanger Regentschappen. "Batavia and its surroundings and the Jakarta Priangan area" include the areas of Tangerang, Karawang, Buitenzorg (Bogor), Cianjur, Bandung, Sumedang and Parakanmuncang ".

2. Het Rijk van Cheribon en Cheribonsche Preanger Regentschappen 'Sultanate of Cirebon and Cirebon-Priangan area include: Cirebon, Limbangan, Sukapura, Galuh.

3. De Noord-Oostkust en den Oosthoek 'The northern coast of the eastern part of Java and the tip of East Java. 
With the division of Daendels, Tangerang is under the perfect supervision of Batavia. In contrast to other areas ruled by natives designated by the colonial government, Perfectur Tangerang remained controlled by landlords. This happened because land in Tangerang was sold and leased to European and Chinese landlords (Staat der Nederlandsche Oost-Indische Bezittingen 1814). Here the orientation is clearly only in the interests of the colonial government and landlords and not the natives. The positions occupied by the natives were only the Chief Prosecutor (Hoofdjaksa) and his deputy (Adjunct Hoofdjaksa) and the Great Chief (Hoofdpanghoeloe) and his Deputy (Adjunct Hoofdpanghoeloe). The position was only about religious matters. Management of the government at a small level held by native people.

The Chinese community is managed by the Chinese themselves. The leader was called mayoor who during the Daendels major was Tan En Goan assisted by as many as 18 people, consisting of 3 captains (Kon Cun Kiat, Tan Kam Long, and Li Pole Ko) and 15 lieutenants. In addition there is the Bengali, Arabic group. Each of which is led by their captain [16]. In Tangerang, a Police Chief (Hoofdschout.) Is assigned. Each district is led by a demang. In addition there is a court institution (landraad). All of the above is regulated in the RR (Regerings Reglement) of 1854.

Batavia is divided into three regions namely North Batavia, West and Southeast Batavia. Each region, including Tangerang, was led by a resident.

With the establishment of Tangerang as the West Kwartier area, officials from the district should have been indigenous people. Indigenous people feel neglected because they have to submit to Chinese landowners. These are the seeds of the antipathy of the indigenous population towards the landlords.

Group problems. The colonial government since the beginning has grouped the citizens based on their ethnicity. The Dutch and Europeans are first-class citizens (De Europeanen). Chinese and Arabs, Indians, Japanese are classified as second-class citizens as Foreign Easterners (De Vreemde Oosterlingen) and native people who should be masters in their own country are classified as third-class citizens, the lowest class (Inlandsch burger).

Educational Problems is a very important thing because educating someone who faces a problem will be wiser. For the Chinese in Tangerang during the colonial period they also paid less attention for education because landlords as rich people did not realize the importance of formal education. They only focus on accumulating as much wealth as possible. Their mindset that someone's prestige will go up if he is rich. Especially with the unavailability of adequate infrastructure, this has hampered the progress of education. Among the lower classes Chinese where many of those are married to their native people do not pass on languages to their children they are more accustomed in communicating with Malay so that their descendants could no longer speak Chinese. All that remains was vocabulary related to religion or beliefs, tool names, culinary terms, kinship terms, and so on.

With more advanced Islamic religious education in Tangerang, the indigenous people are even more untouched by the Government because the Government realizes that the problem of religion is a very sensitive issue. Therefore there is no close relationship between the natives and the Dutch as a government and between the natives and the Chinese [17]. The uprising led by Kaiin was a manifestation and excess of the policies of the racist Dutch East Indies Colonial Government. The colonial wounds at any time could surface not only in the past colonial period, but could re-emerge in the Republic of Indonesia's current independence. If the Government is not wise in dealing with economic problems and pluralism throughout the country, then the possibility of upheaval with ethnic background can occur. The government is better to learn from the history of Tangerang. A fight between a number of residents of Kampung Tegalkunir and with the Kebonbaru Chinese. The fight is based on the sentiment to 
Chinee people. The problem of trivial misunderstanding but because of exhaled ethnic problems it becomes out of control. The reason is only trivial that the son of a Gudel farmer's son of Kebon Baru is suspected of not paying when buying sticky rice at the son of Lim Oetan who owns rice fields there [18].

\section{Conclusion}

In terms of topology according to the results of this study is the word tenger or tengeran it means sign (Bantams-language) is a marking in the form of a monument or river as a geographical boundary as done between the Sultan of Bantam with the VOC. In this case the Cisadane river be pointed as a barrier between Jayakarta and Bantam. At the end of the 17th century with the expansion of the Company's territory, a boundary was established in Grendeng to the west of the Cisadane river, which was erected by what the Bugines guardians of the Makassar Fortress called, pronounced as [tangarang] and eventually became [tangerang]. Tangerang during the heyday of Bantam included into the Jayakarta region. For more than 80 years Tangerang has been in the position of two opposing forces namely the Sultanate of Bantam and Batavia. Tangerang became a destination for domiciled by losing troops fighting in Batavia. The population increased after there was a ban on the Chinese not being allowed to live in the city of Batavia after the end of the riots of ethnic Chinese massacre in Batavia 1740. The discriminatory politics of the colonial government in compartmentalizing society based on golongans (ethnic groups) actually triggered a sense of disappointment and indigenous jealousy towards the Government and ethnic Chinese . As a result, ethnic Chinese have always been the victims of such discriminatory Government policies. The Indonesian government after the Reformation must learn from the history of Tangerang if it will implement a variety of main policies relating to issues of ethnicity, social economy and pluralism in the Republic of Indonesia. Hopefully this description adds a little insight and we can learn about the history of the city of Tangerang, which is very closely related to the implementation of government policy during the colonial period.

Thank you.

\section{References}

[1] T. History, S. Society, and C. Press, "Review Reviewed Work ( s ): The Suma Oriental of Tomé Pires by Armando Cortesão Review by: G . S . Published by: The University of Chicago Press on behalf of The History of Science Society Stable URL : https://www.jstor.org/stable/225461 The History of ," pp. 24-25, 2019.

[2] H. J. De Graaf, “Tomé Pires’ „Suma Oriental“ En Het Tijdperk Van Godsdienstover. Gang Op Java," Bijdr. tot Taal-, Land- en Volkenkd., vol. 108, no. 2, pp. 132-171, 1952.

[3] J. Noorduyn, "Concerning The Reliability Of Tomé Pires' Data On Java," Bijdr. tot Taal-, Landen Volkenkd., vol. 132, no. 4, pp. 467-471, 1976.

[4] L. Blussé, "Batavia, 1619-1740: The Rise and Fall of a Chinese Colonial Town," J. Southeast Asian Stud., vol. 12, no. 1, pp. 159-178, 1981.

[5] R. Parthesius, "The Dutch expansion in Asia up to 1660," in Dutch Ships in Tropical Waters, Amsterdam University Press, 2010, Pp. 31-50.

[6] R. Van Der Aa., J. V. S. Van Gollonesse, J. G. Loten, And W. H. Van Ossenberch, "De Groote Bantamsche Opstand In Het Midden Der Vorige Eeuw, Bewerkt Naar meerendeels onuitgegeven bescheiden uit het oud-koloniaal archief met drie officiëele documenten als bijlagen," Bijdr. tot 
Taal-, Land- en Volkenkd. van Ned., vol. 29, no. 1, pp. 1-127, 1881.

[7] M. Somers, A. L. Half-century, and M. S. Heidhues, "Studying the Chinese in Indonesia: A Long Half-Century Stable URL : https://www.jstor.org/stable/44668440 Studying the Chinese in Indonesia :," vol. 32, no. 3, pp. 601-633, 2019.

[8] L. Blusse, "Department of History , National University of Singapore Batavia , 1619-1740 : The Rise and Fall of a Chinese Colonial Town Author ( $\mathrm{s}$ ): Leonard Blussé Source: Journal of Southeast Asian Studies, Vol . 12 , No . 1, Ethnic Chinese in Southeast Asia Pub,” vol. 12, no. 1, pp. 159-178, 2019.

[9] C. Norris, Membongkar teori dekonstruksi jacques derrida. Ar-Ruzz, 2003.

[10] G. R. Knight, "John Palmer And Plantation Development In Western Java During The Earlier Nineteenth Century," Bijdr. tot Taal-, Land- en Volkenkd., vol. 131, no. 2/3, pp. 309-337, 1975.

[11] P. CAREY, "Into a new era:," in The Power of Prophecy, vol. 249, Brill, 2007, pp. 345-430.

[12] J. Breman, "Government regulated exploitation versus private agribusiness," in Mobilizing Labour for the Global Coffee Market, Amsterdam University Press, 2015, pp. 129-168.

[13] A. A. Sneller, "Seventeenth-century Dutch pamphlets as a source of political information," From Revolt to Riches, pp. 196-206, 2018.

[14] A. Ota, "Banten Rebellion, 1750-1 752 : Factors behind the Mass Participation," vol. 37, no. 3, pp. 613-651, 2019.

[15] J. BASTIN, "The Beginnings Of The Land Rent System In Java," in Raffles' Ideas on the Land Rent System in Java and the Mackenzie Land Tenure Commission, vol. 14, Brill, 1954, pp. 1548.

[16] L. Tzû-jan, K. Hsing, C. Hsi-Chih, and L. Suryadinata, "The Structure of the Indonesian Chinese Society,” Southeast Asian J. Soc. Sci., vol. 9, no. 1/2, pp. 130-132, 1981.

[17] B. Hoetink, "Ni Hoekong Kapitein Der Chineezen Te Batavia In 1740," Bijdr. tot Taal-, Landen Volkenkd. van Ned., vol. 74, no. 4, pp. 447-518, 1918.

[18] K. Saddhono and S. Supeni. "The role of dutch colonialism in the political life of Mataram dynasty: A case study of the manuscript of Babad Tanah Jawi." Asian Soc. Sci. vol. 10 no.15 pp. $1-7,2014$ 